\title{
Correction to: The implicit preference of bibliometrics for basic research
}

\author{
Paul Donner $^{1}$ (iD . Ulrich Schmoch ${ }^{2}$ (D)
}

Published online: 6 November 2021

(C) The Author(s) 2021

\section{Correction to: Scientometrics (2020) 124:1411-1419 https://doi.org/10.1007/s11192-020-03516-3}

The article "The implicit preference of bibliometrics for basic research", written by Paul Donner and Ulrich Schmoch, was originally published Online First without Open Access. After publication in volume 124, issue 2, page 1411-1419 the author decided to opt for Open Choice and to make the article an Open Access publication. Therefore, the copyright of the article has been changed to (OThe Author(s) 2021 and the article is forthwith distributed under the terms of the Creative Commons Attribution 4.0 International License, which permits use, sharing, adaptation, distribution and reproduction in any medium or format, as long as you give appropriate credit to the original author(s) and the source, provide a link to the Creative Commons licence, and indicate if changes were made. The images or other third party material in this article are included in the article's Creative Commons licence, unless indicated otherwise in a credit line to the material. If material is not included in the article's Creative Commons licence and your intended use is not permitted by statutory regulation or exceeds the permitted use, you will need to obtain permission directly from the copyright holder. To view a copy of this licence, visit http://creativecommons.org/licen ses/by/4.0. Open Access funding enabled and organized by Projekt DEAL.

The original article has been corrected.

Open Access This article is licensed under a Creative Commons Attribution 4.0 International License, which permits use, sharing, adaptation, distribution and reproduction in any medium or format, as long as you give appropriate credit to the original author(s) and the source, provide a link to the Creative Commons licence, and indicate if changes were made. The images or other third party material in this article are included in the article's Creative Commons licence, unless indicated otherwise in a credit line to the material. If material is not included in the article's Creative Commons licence and your intended use is not permitted by statutory regulation or exceeds the permitted use, you will need to obtain permission directly from the copyright holder. To view a copy of this licence, visit http://creativecommons.org/licenses/by/4.0/.

The original article can be found online at https://doi.org/10.1007/s11192-020-03516-3.

Ulrich Schmoch

us@isi.fhg.de

Paul Donner

Donner@dzhw.eu

1 Deutsches Zentrum für Hochschul- und Wissenschaftsforschung (DZHW), Berlin, Germany

2 Fraunhofer ISI, Karlsruhe, Germany 